\title{
BODIPY Dye Embedded Electrospun Polystyrene Nanofibers for the Photocatalytic Degradation of Orange G in Industrial Wastewaters
}

\author{
Augustus K. Lebechi, Tebello Nyokong, ${ }^{@}$ and John Mack ${ }^{@}$ \\ Dedicated to Prof. Aslan Y. Tsivadze on the occasion of his Birthday \\ Centre for Nanotechnology Innovation, Department of Chemistry, Rhodes University, 6140 Grahamstown, South Africa \\ ${ }^{\circledR}$ Corresponding authorsE-mail: t.nyokong@ru.ac.za; j.mack@ru.ac.za
}

\begin{abstract}
The potential utility of electrospun polystyrene (PS) nanofibers embedded with 2,6-dibromo-8-pyrenyl-1,3,5,7-tetramethyl BODIPY for the photocatalytic degradation of Orange $G$ in wastewaters is investigated. A comparison of the singlet oxygen quantum yield of the BODIPY dye in solution and when embedded in the PS nanofibers demonstrates that its photosensitizer properties are maintained in the nanofiber mats. The photocatalytic degradation properties of the PS nanofibers for Orange $G$ were determined using a $530 \mathrm{~nm}$ light emitting diode. The rate of photodegradation increases with the Orange $G$ concentration and follows pseudo-first order kinetics at $p H$ 6.7. Reusability studies demonstrate that there is an enhancement in the rate of degradation when the fibers are reused.
\end{abstract}

Keywords: BODIPY dyes, nanofibers, singlet oxygen, photodegradation.

\section{Фотокаталитическая деградация красителя Оранжевого Ж в промышленных сточных водах на нановолокнах полистирола, модифицированных BODIPY}

\author{
А. К. Аебечи, Т. Ниоконг, ${ }^{@} \triangle$ Аж. Мак ${ }^{@}$ \\ Центр инноваций в области нанотехнологии, кафедра химии, Университет Родса, 6140 Грэхэмстаун, ЮАР \\ @E-mail:t.nyokong@ru.ac.za; j.mack@ru.ac.za
}

\begin{abstract}
Рассмотрена возможность использования нановолокон полистирола (PS), содержсачих встроенный 2, 6-дибром8-пиренил-1,3,5,7-тетраметил-ВОDIPY, для фотокаталитической деградации Оранжевого G в сточных водах. Сравнение квантового выхода синглетного кислорода красителя ВОDIРY в растворе и при встраивании в нановолокона PS показывает, что его фотосенсибилизирующие свойства в составе нановолокон сохраняются. Фотокаталитическое влияние модифицированных нановолокон PS на деградацию Оранжевого $G$ изучалось с помощью светоизлучающего диода с длиной волны 530 нм. Скорость фотодеградации увеличивается с ростом концентрации Оранжевого G и соответствует кинетике псевдо-первого порядка при рН 6,7. При повторном использовании волокон наблюдается увеличение скорости деградации.
\end{abstract}

Ключевые слова: BODIPY краситель, нановолокна, синглетный кислород, фотодеградация. 


\section{Introduction}

The contamination of freshwater by azo dyes in textile industry effluents remains a significant environmental problem and this leads to a need for wastewater remediation. ${ }^{[1]}$ Various physicochemical and biological techniques such as filtration, coagulation, precipitation, adsorption, ion exchange and oxidation have been used for the removal of Orange $\mathrm{G}$ in this context. Physicochemical dye removal methods are only effective when small volumes of effluent are involved, and are therefore not generally cost effective. ${ }^{[2]}$ Advanced oxidation mechanisms have proven their efficacy in degrading recalcitrant organic dye pollutants in wastewater ${ }^{[3]}$ The photocatalytic oxidation of pollutants has significant advantages over other approaches since it generally does not lead to the release of harmful by-products. This approach has been employed in this work for the photodegradation of Orange $\mathrm{G}$, an azo dye found mostly in wastewaters from textile industry effluents. During photocatalysis, reactive oxygen species (ROS) such as ${ }^{1} \mathrm{O}_{2}\left({ }^{1} \Delta_{\mathrm{g}}\right)$ are utilized in mineralizing pollutants to less hazardous compounds, and photosensitizer dyes generate ${ }^{1} \mathrm{O}_{2}$ upon irradiation with light of appropriate wavelength. ${ }^{[4]}$

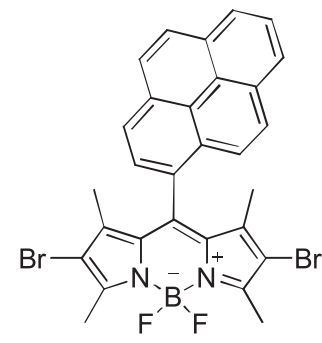

Figure 1. The molecular structure of 2,6-dibromo-8-pyrenyl1,3,5,7-tetramethylBODIPY $\mathbf{1}$.

In recent years, there has been considerable interest in the use of phthalocyanines, which absorb strongly at the red and blue ends of the visible region, as photocatalysts for the degradation of Orange $G$ in wastewaters. ${ }^{[5,6]}$ The absence of significant absorbance in the green portion of the visible region means that not all of the incident light can be absorbed when white light sources are used, so introducing a second chromophore could further enhance the utility of photosensitizer dye embedded polymer nanofibers for the photodegradation of organic pollutants. In this work, we report the use of 2,6-dibromo-8-pyrenyl-1,3,5,7-tetramethylBODIPY (1) (Figure 1) immobilized on nanofibers as ${ }^{1} \mathrm{O}_{2}$ generating heterogeneous photocatalysts for the mineralization of Orange G. Immobilization of the dye on a solid support provides the advantages of catalysts recovery and recycling unlike in the corresponding homogenous systems. ${ }^{[6]}$ Nanofibers have specific surface area, highly porous, making it possible to immobilize different functional groups on their surfaces. ${ }^{[6-8]}$ Polystyrene was chosen for the nanofiber studies because of its resistance to heat, durability and ability to form a stronger $\pi-\pi$ interaction with the dye.

In the last few decades, there has been considerable interest in BODIPY dyes due to their favorable photophysical properties, such as high fluorescence and singlet oxy- gen quantum yields, negligible sensitivities to temperature and solvents, with large extinction coefficients in the visible region. ${ }^{[9]}$ BODIPY dyes are dipyrrin structural analogues of porphyrins with extended $\pi$-conjugation systems that possess good chemical and photostability, due to the rigid structure that is formed upon coordination by $\mathrm{BF}_{2} \cdot{ }^{[10]}$ Their facile synthesis, and the ability to functionalize eight positions of the BODIPY core, enable the wavelengths of their emission and absorption bands to be fine-tuned, ${ }^{[11]}$ and this has led to research on applications in diverse fields including electrocatalysis, as fluorescence sensors, photosensitizers in photodynamic therapy (PDT), and in photocatalysis. ${ }^{[12,13]}$ BODIPY dyes can be functionalized with halogens such as bromine or iodine to significantly enhance the rate of intersystem crossing through spin orbit coupling. ${ }^{[1]}$ In the triplet excited state, energy from the photoexcited electrons of the dye are transferred to triplet ground state molecular oxygen to generate triplet excited singlet oxygen species that photodegrades the pollutants. ${ }^{[5-7]}$ BODIPY dyes have previously been used to modify electrospun fibers, and these modifications did not change the physicochemical properties of the dye. ${ }^{[14]}$ Although the use of BODIPY dyes as photocatalysts in organic transformations has been reported previously, ${ }^{[15]}$ to the best of our knowledge, there have been no previous studies of the potential utility of BODIPY dyes modified nanofibers for the photocatalytic degradation of organic dye pollutants.

\section{Experimental}

\section{Materials}

Anthracene-9,10-bismethylmalonate (ADMA), Orange G and polystyrene (PS, Mw $=192,000 \mathrm{~g} \cdot \mathrm{mol}^{-1}$ ) were purchased from Sigma-Aldrich. Acetic acid (glacial), tetrahydrofuran (THF) and dimethylformamide (DMF) were purchased from Saarchem, while Rose Bengal was purchased from Fluka. Water collected from milli-Q water (Millipore corp., Bedford, MA, USA) was used for the preparation of all aqueous solutions. All solvents were dried prior to use using molecular sieves. BODIPY 1 was synthesized using the method described previously described (Figure 1). ${ }^{[16]}$

\section{Equipment}

A scanning electron microscope (SEM, JOEL JSM 840 scanning electron microscope) operating at an accelerating voltage of $20 \mathrm{kV}$ was used to determine the morphology of the electropsun nanofibers. The average nanofiber diameters together with standard deviations were determined from 70 measurements using the Cell D software package from Olympus. An Inca PentaFET Precision coupled to a Vega Tescam operating at a $20 \mathrm{kV}$ accelerating voltage was used to collect the energy dispersive X-ray spectroscopy (EDX) data. UV-Visible absorption spectra were measured at room temperature on a Shimadzu UV-2550 spectrophotometer using a $1 \mathrm{~cm}$ path length cuvette for solution studies and a Perkin Elmer Lambda $950 \mathrm{UV}$-Vis spectrophotometer for solid state measurements. ${ }^{1} \mathrm{H}$ NMR spectra were recorded in THF on a Bruker AMX 600 spectrometer operating at $600 \mathrm{MHz}$. Mass spectrometry (MS) measurements were performed on a Bruker Autoflex 111 smartbeam TOF/ TOF mass spectrometer. The instrument was operated in positive ion mode over a $400-3000 \mathrm{~m} / \mathrm{z}$ range. The voltage of the ion source was set at 19.0 and $16.7 \mathrm{kV}$ for ion sources 1 and 2 respectively, while the lens was set at $8.50 \mathrm{kV}$. The MS data were recorded using $\alpha$-cyano-4-hydroxycinnamic acid as the MALDI matrix, by using a $337 \mathrm{~nm}$ nitrogen laser. Fluorescence spectra were measured on 
a Variant Eclipse spectrofluorimeter. Singlet oxygen studies for both the BODIPY solution and BODIPY 1 embedded PS nanofibers were conducted by using an Ekspla NT 342B-20-AW-Nd:YAG laser. Measurement of fluorescence lifetimes was performed by using a time correlated single photon counting (TCSPC) instrument (FluoTime 200, Picoquant). The excitation source was a diode laser (LDH-PC-485 with $10 \mathrm{MHz}$ repetition rates, 88 ps pulse).

\section{Electrospinning}

The PS pellets were dissolved in 8:2 dimethylformamide (DMF) and tetrahydrofuran (THF) to form $30 \mathrm{~mL}$ of a $20 \mathrm{wt} \%$ solution by stirring for $24 \mathrm{~h}$ at room temperature. Functionalization of the nanofibers was achieved by adding 10 or $15 \mathrm{mg}$ of brominated BODIPY 1 to the PS solutions and then stirring overnight. During electrospinning, functionalized and unfunctionalized solutions were prepared in a $20 \mathrm{~mL}$ syringe fitted with a hypodermic needle (inner diameter of $0.1 \mathrm{~mm}$ ) at $0.1 \mathrm{~mL} \cdot \mathrm{h}^{-1}$ and a tip to collector distance (TCD) of $13 \mathrm{~cm}$. The solutions were electrospun at 20 $\mathrm{kV}$ onto a grounded collector covered with foil where the solidified fibers were collected at ambient temperature and $48 \%$ humidity.

\section{Photodegradation}

Photodegradation measurements were carried out by using a Thorlabs mounted M530L3 LED as the light source. The LED was mounted into the housing for a Modulight Medical Laser system that was equipped with a magnetic stirrer and a sample holder with a spot diameter of $5.5 \mathrm{~cm}$. The LED provided an irradiance of $350 \mathrm{~mW} \cdot \mathrm{cm}^{-2}$ in this context for an overall duration of $30 \mathrm{~min}$ with spectral readings taken at $5 \mathrm{~min}$ intervals to monitor progress. Prior to the photodegradation experiments the fiber mats were immersed in a solution of Orange $\mathrm{G}$ solution for $30 \mathrm{~min}$ to reach an absorption-desorption equilibrium for Orange $\mathrm{G}$ and dissolved oxygen on the surface of the catalyst.

\section{Photophysical and photochemical properties}

Fluorescence quantum $\left(\Phi_{\mathrm{F}}\right)$ yield was determined by comparing the integrated intensity of the BODIPY dye and that of a known standard using the comparative method. ${ }^{[17]}$ Rhodamine $6 \mathrm{G}$ was employed as a standard in this study with $\left(\Phi_{\mathrm{F}}=0.94\right.$ in ethanol $) .{ }^{[18]}$ The singlet oxygen quantum yield $\left(\Phi_{\Delta}\right)$ value of BODIPY 1 was studied through a comparative method by monitoring the photo-oxidation of 1,3-diphenylisobenzofuran (DPBF) at different time intervals with Rose Bengal used as the standard $\left(\Phi_{\Delta}=0.76\right.$ in ethanol). ${ }^{[19]}$ Studies to determine the $\Phi_{\Delta}$ value of the BODIPY dye embedded PS nanofibers were carried out using the direct chemical method due to a lack of suitable standards. The studies were performed in aqueous solution using ADMA as a chemical quencher; the modified fibers were suspended in the aqueous solution of ADMA. The quantum yield $\left(\Phi_{\mathrm{ADMA}}\right)$ was first calculated using Eq. (1):[20]

$$
\Phi_{\mathrm{ADMA}}=\left(C_{0}-C_{\mathrm{t}}\right) \cdot \mathrm{V}_{\mathrm{R}} / I_{\mathrm{Abs}} \cdot \mathrm{t},
$$

where $C_{0}$ and $C_{\mathrm{t}}$ are ADMA concentrations before and after irradiations, $\mathrm{V}_{\mathrm{R}}$ is the solution volume; $\mathrm{t}$ represents irradiation time per cycle and $I_{\text {Abs }}$ is defined by Eq. (2):

$$
I_{\mathrm{Abs}}=(\alpha \cdot \mathrm{A} \cdot I) / \mathrm{N}_{\mathrm{A}},
$$

where $\alpha=1-10^{-\mathrm{A}(\lambda)}$ and $\mathrm{A}(\lambda)$ is the absorbance value of the sensitizer at the irradiation wavelength, $\mathrm{A}$ is the irradiated area $\left(2.5 \mathrm{~cm}^{2}\right), I$ is light intensity $\left(3.32 \cdot 10^{17}\right.$ photons $\left.\cdot \mathrm{cm}^{-2} \cdot \mathrm{s}^{-1}\right)$ and $\mathrm{N}_{\mathrm{A}}$ is Avogadro's constant. Singlet oxygen calculations were carried out by using Eq. (3):

$$
1 / \Phi_{\text {ADMA }}=\left(1 / \Phi_{\Delta}\right)+\left(1 / \Phi_{\Delta}\right) \cdot\left(K_{\mathrm{d}} / K_{\mathrm{a}}\right) \cdot(1 /[\mathrm{ADMA}]),
$$

where $K_{\mathrm{a}}$ denotes the rate constant for the reaction of ADMA with ${ }^{1} \mathrm{O}_{2}$, and $K_{\mathrm{d}}$ represents the decay constant of singlet oxygen. The $\Phi_{\Delta}$ value is obtained from the intercept of the plot of $1 / \Phi_{\mathrm{ADMA}}$ against $1 /[\mathrm{ADMA}]$. In Eq. (2) the absorbance value used is that of the BODIPY modified nanofibers and this was measured by placing the fibers on a glass slide. Since some of the incident light is expected to be scattered, the $\Phi_{\Delta}$ value of BODIPY dyes in the fiber should be viewed only as an estimate.

\section{Results and Discussion}

\section{Optical spectroscopy of BODIPY 1}

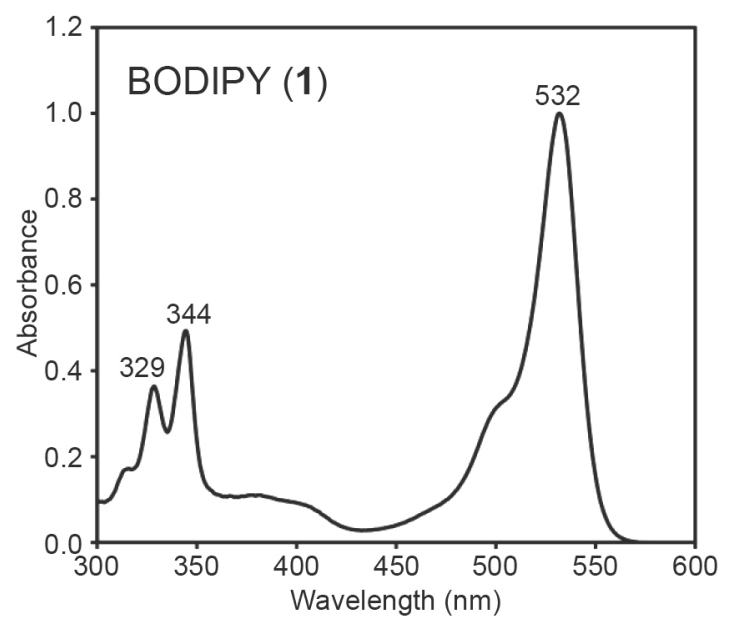

Figure 2. UV-Visible absorption spectrum of BODIPY 1 in DMSO.

The ground state electronic absorption spectra of BODIPY 1 in DMSO has an intense band at 532 $\mathrm{nm}$ (Figure 2), about $30 \mathrm{~nm}$ to the red of where the main BODIPY spectral band normally lies due to the bromination at the 2,6-positions. ${ }^{[16,21]}$ The bands at 329 and $344 \mathrm{~nm}$ in the UV region are associated with the meso-pyrenyl ring. When BODIPY 1 was embedded in electrospun PS nanofibers at dye loadings of 10 and $15 \mathrm{mg}$, the solid state absorption spectra shown in Figure 3 were obtained. There is significant broadening due to aggregation, which is more pronounced in the fibers prepared with $15 \mathrm{mg}$ of dye.

\section{Characterization of the electrospun nanofibers}

Electrospinning has proven to be a versatile and cost effective method for producing long continuous nanofibers with diameters ranging from several micrometers down to a few nanometers. ${ }^{[7]}$ Study of the morphology and diameter of the electrospun nanofibers was done by using SEM (Figure 4). Prior to functionalisation, studies were done to optimize the parameters using polymer solutions of varying concentrations. SEM images revealed fibers with junctions and beads at lower polymer concentration. To obtain uniform continuous fibers with no beads and junctions, electrospinning parameters such as viscosity of the polymer solution, flow rate, voltage and the TCD were carefully optimized (20 wt \% polymer, flow rate $0.1 \mathrm{~mL} \cdot \mathrm{h}^{-1}, 20 \mathrm{kV}, 13 \mathrm{~cm}$ ). Although fiber diameters were relatively similar due to electrospinning under similar conditions, there was a noticeable 


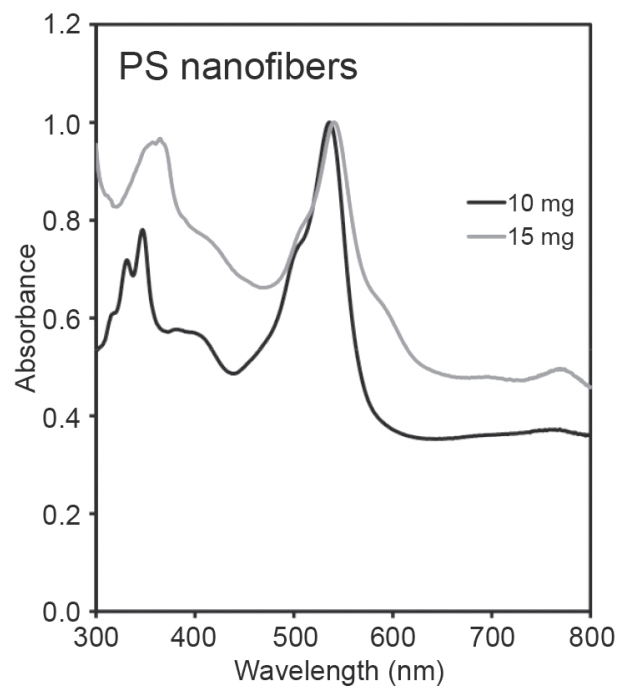

Figure 3. Solid state UV-Visible absorption spectra of BODIPY 1 embedded PS nanofibers with different dye loadings.

increase for fibers containing a $15 \mathrm{mg}$ loading of BODIPY $1(2.2 \mu \mathrm{m})$ as opposed to $10 \mathrm{mg}(1.9 \mu \mathrm{m})$. Since polystyrene is an aromatic polymer, there is scope for enhanced $\pi-\pi$ stacking and hydrophobic interactions between the pyrene ring of BODIPY 1 and the aromatic region of polystyrene. EDX data were obtained to determine the chemical composition of the fibers produced and was expected to indicate successful incorporation of BODIPY dyes into the fiber matrix. The EDX spectra of the functionalised and unfunctionalized fibers shown in Figure 5 confirm the presence of BODIPY $\mathbf{1}$, since $\mathrm{Br}, \mathrm{B}$ and $\mathrm{F}$ are present in the spectrum of the functionalized fiber.

\section{Photophysical properties}

The $\Phi_{\mathrm{F}}$ value for BODIPY 1 was found to be 0.05 in DMSO, which is relatively low, as would be anticipated since the heavy atom effect of halogen atoms at the 2,6-positions enhances intersystem crossing to the triplet state. The $\Phi_{\Delta}$ value was determined to be 0.86 by using a comparative method with DPBF as a ${ }^{1} \mathrm{O}_{2}$ scavenger, Figure 6 . The absence of significant spectral changes for the main BODIPY spectral band in the $500-555 \mathrm{~nm}$ range is an indication that BODIPY 1 exhibits high photostability and is resistant to photobleaching, Figure 6. Since the role of ${ }^{1} \mathrm{O}_{2}$ in photocatalytic degradation is of great significance, there is a need to determine the $\Phi_{\Delta}$ value of the modified fibers which are to be used for the photocatalytic studies in aqueous media. This was accomplished in buffered solution ( $\mathrm{pH}$ 6.7), with ADMA used as the ${ }^{1} \mathrm{O}_{2}$ scavenger, Figure 7. Prior to irradiation, 20 $\mathrm{mg}$ of the modified fibers was submerged in an aqueous solution of ADMA and irradiated for $180 \mathrm{~s}$, Figure 7. The degradation of ADMA was monitored at $380 \mathrm{~nm}$. The $\Phi_{\Delta}$ value of the BODIPY 1 embedded PS nanofibers was estimated to be 0.25 . This demonstrates that BODIPY 1 maintains its singlet oxygen production properties in the fibers making the modified fibers suitable for photocatalytic degradation.

\section{Photodegradation of Orange $G$}

The modified fibers with a $10 \mathrm{mg}$ loading of BODIPY $\mathbf{1}$ were evaluated spectroscopically for photocatalytic efficiency by monitoring the degradation of Orange $G$ after irradiations with a Thorlabs $530 \mathrm{~nm}$ mounted LED at five minutes intervals, Figure 8, since its output closely matches the wavelength range of the main absorption band of BODIPY $\mathbf{1}$ at $532 \mathrm{~nm}$, Figure 2. Upon irradiation, there was an observed
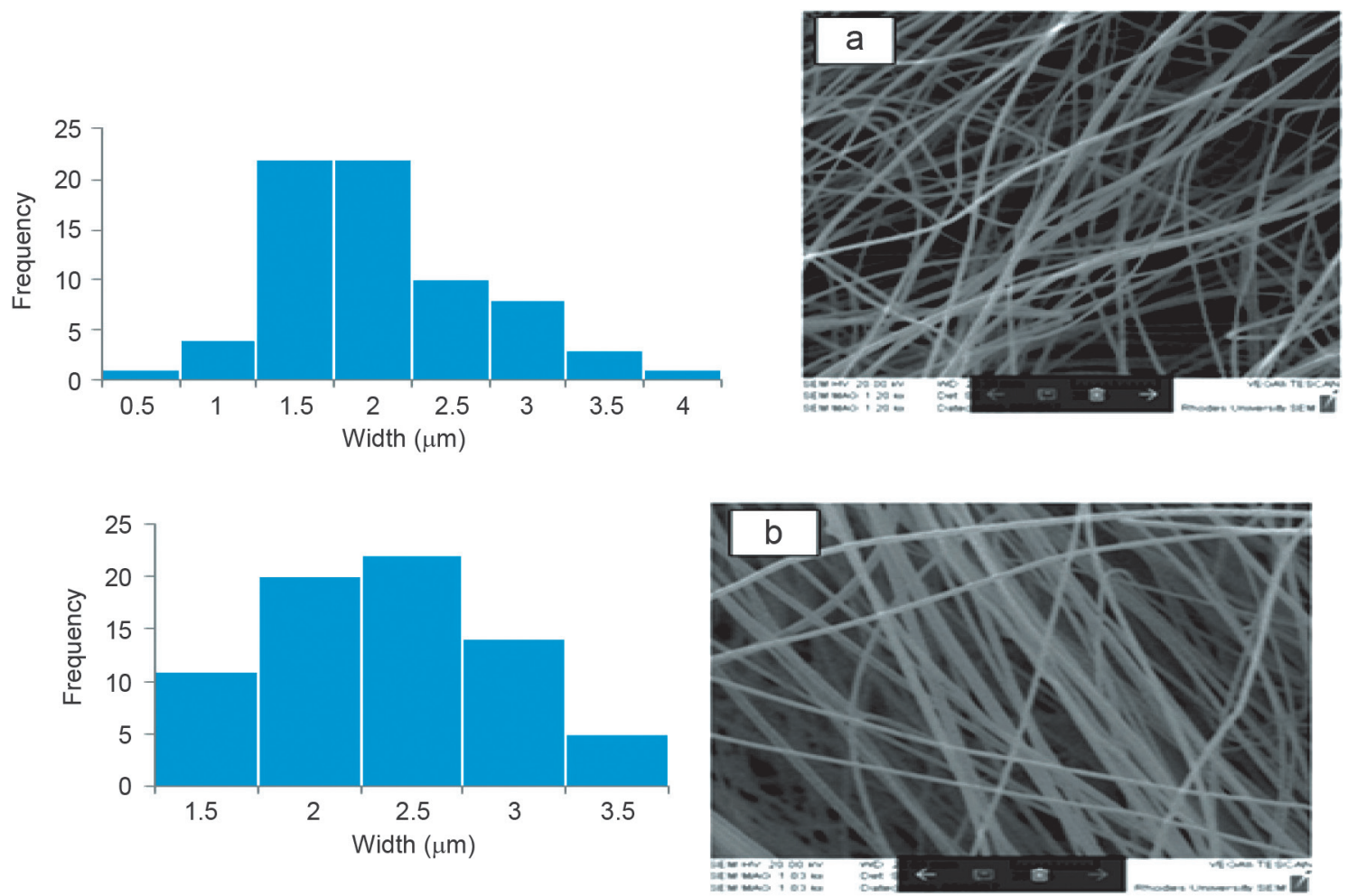

Figure 4. SEM micrograph of the functionalized nanofiber mats (a) $10 \mathrm{mg}$ and (b) $15 \mathrm{mg}$ of BODIPY 1. 


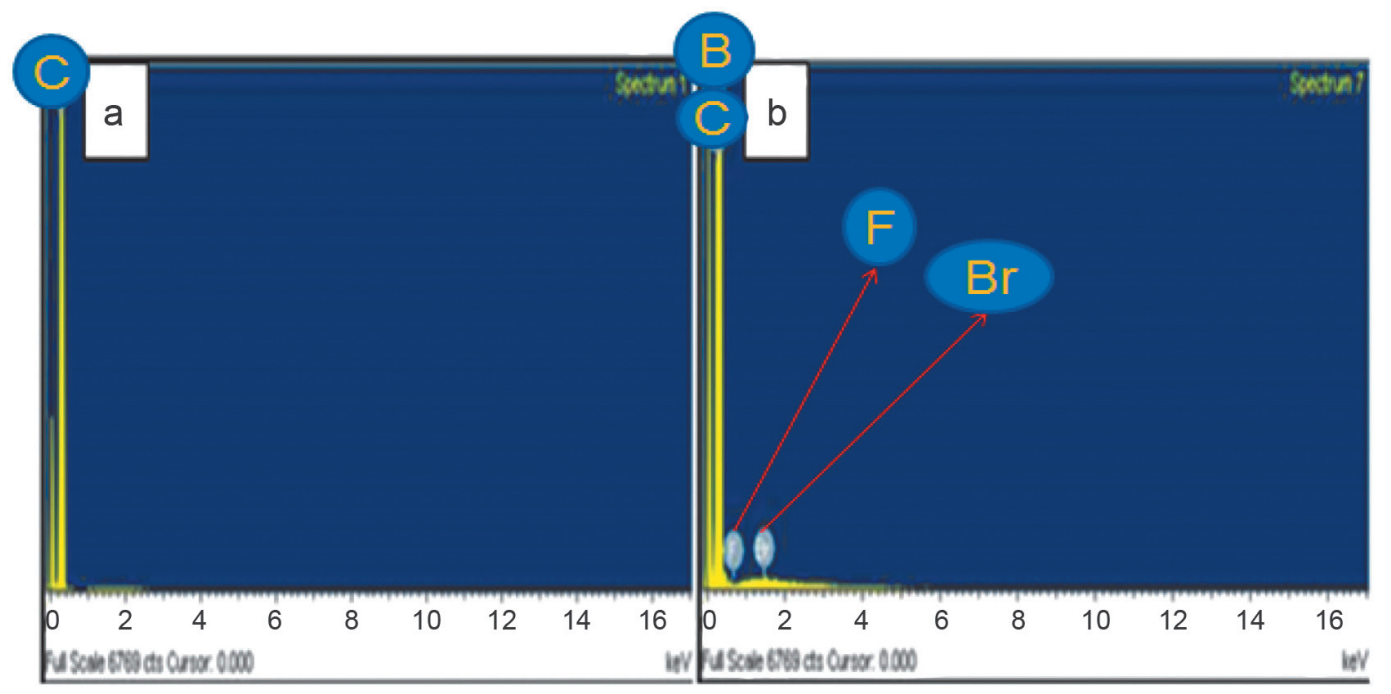

Figure 5. EDX spectra of (a) unfunctionalized PS nanofibers and (b) BODIPY 1 embedded PS nanofiber mats.

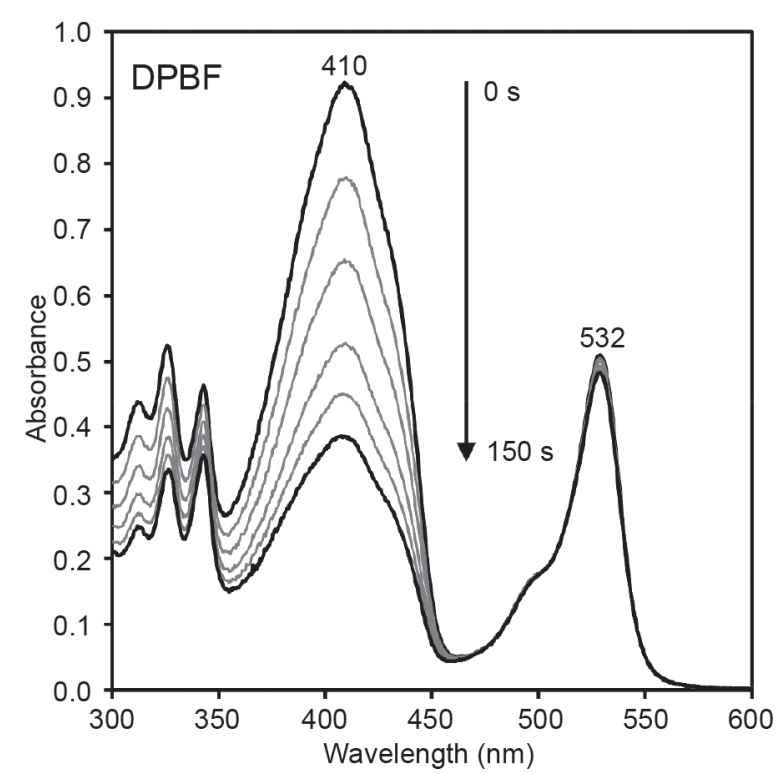

Figure 6. Photocatalytic degradation of $\operatorname{DPBF}\left(\lambda_{\max }=410 \mathrm{~nm}\right)$ in ethanol by $1\left(\lambda_{\max }=532 \mathrm{~nm}\right)$ at $30 \mathrm{~s}$ intervals.

decrease in the intensity of the absorption band of Orange $\mathrm{G}$ spectra at $478 \mathrm{~nm}$ as shown in Figure 8. Previous studies show that amongst others, the reactions that occur during Orange $\mathrm{G}$ photolysis include hydroxylation of the aryl group, desulfonation and the oxidative cleavage of an azo group. ${ }^{\text {[22] }}$ No spectral changes were observed when unmodified PS nanofibers were used for Orange $\mathrm{G}$ photocatalysis, and this demonstrates that the fiber alone has no catalytic contribution and hence only functions as a support system for the photosensitizer. The rate of Orange $\mathrm{G}$ photodegradation versus irradiation time was monitored as shown in Figure 9. Kinetic data are listed in Table 1 . When $\ln \left(C_{0} / C\right)$ was plotted against irradiation time at the following concentrations; (i) $4.1 \cdot 10^{-5}$, (ii) $6.4 \cdot 10^{-5}$, (iii) $9.3 \cdot 10^{-5}$, and (iv) $11.8 \cdot 10^{-5}$ (Figure 9), linear plots were obtained. This provides an indication that the reaction follows approximately pseudo-first order kinetics with respect to Orange $\mathrm{G}$ and fits the equation given by:

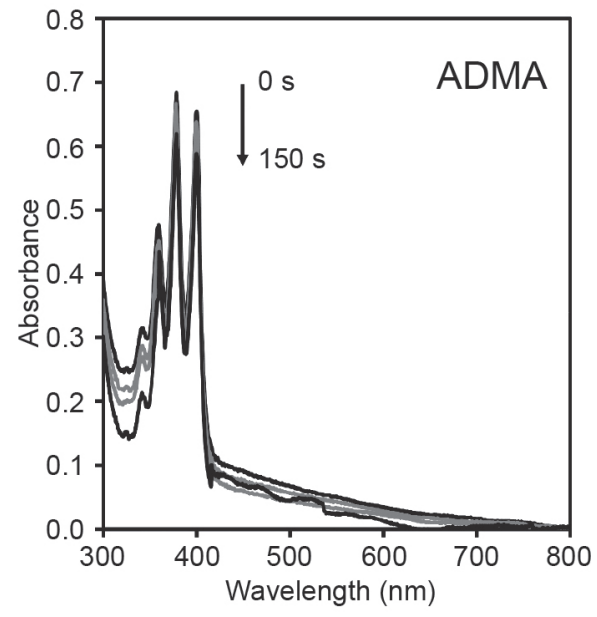

Figure 7. UV-Visible absorption changes observed following the photolysis of ADMA in an aqueous solution for $150 \mathrm{~s}$ with $25 \mathrm{mg}$ of a BODIPY 1 embedded PS nanofiber suspended in solution. The initial concentration of ADMA was $5.2 \cdot 10^{-5} \mathrm{~mol} \cdot \mathrm{L}^{-1}$.

$$
k_{\mathrm{obs}}=\ln \left(C_{0}-C_{\mathrm{t}}\right) / \mathrm{t} \text {, }
$$

where $C_{0}$ is the initial concentration, and $C_{\mathrm{t}}$ is the concentration at a time t. The $k_{\text {obs }}$ value is the observed reaction rate constant, which is obtained from the slope of the line in the plot of $\ln \left(C_{0} / C\right)$ versus $t$ (Figure 9). The decrease in concentration associated with this can be related at any given time by the photodegradation percentage $(\eta)$ using the following relationship:

$$
\eta=\left(1-C / C_{0}\right) \cdot 100
$$

When the nanofibers were reused, an enhancement in the initial rate of photodegradation was observed over the entire range of concentrations studied (Figure 10A). The percentage of degradation after $30 \mathrm{~min}$ was found to increase significantly with the initial Orange G concentration [OG] (Table 1) 


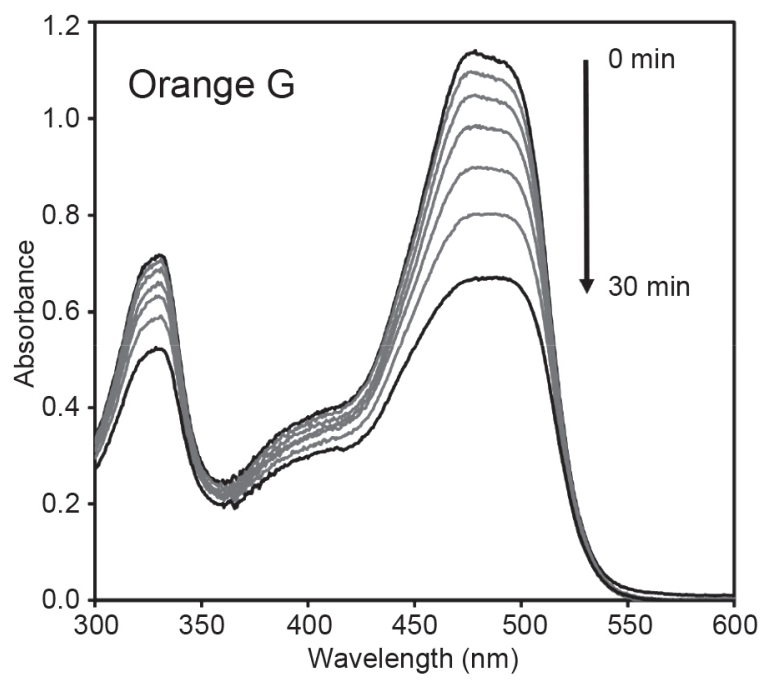

Figure 8. UV-Visible absorption changes measured at $5 \mathrm{~min}$ intervals during the photocatalysis of Orange $\mathrm{G}$ with a $530 \mathrm{~nm}$ LED using $20 \mathrm{mg}$ of BODIPY 1 PS nanofibers at $\mathrm{pH} 6.7$.

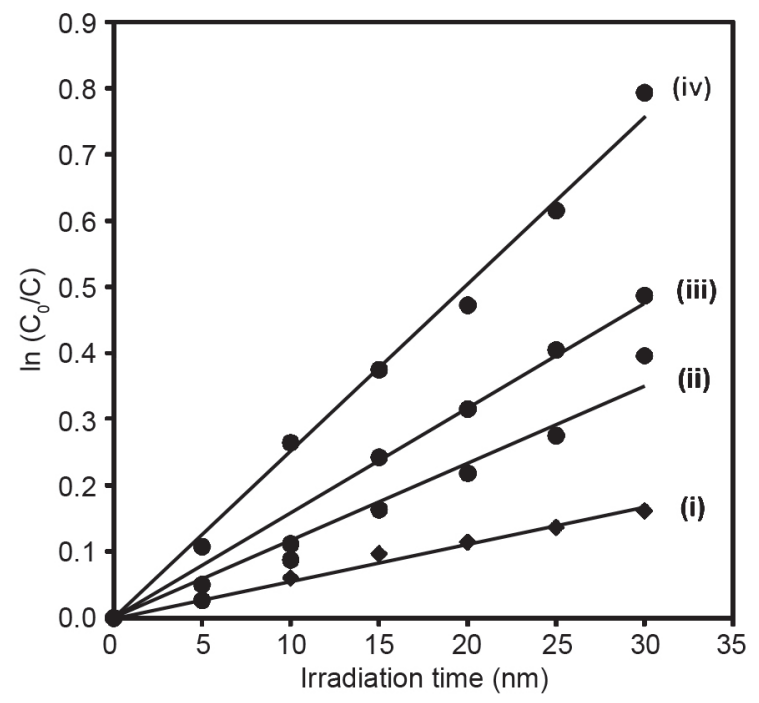

Figure 9. Plots for the photodegradation of Orange G; (i) $4.1 \cdot 10^{-5}$, (ii) $6.4 \cdot 10^{-5}$, (iii) $9.3 \cdot 10^{-5}$, and (iv) $11.8 \cdot 10^{-5} \mathrm{~mol}^{-1} \cdot \mathrm{L}$ using BODIPY 1 PS nanofibers. and half-life $(\tau)$ values range from $28 \mathrm{~min}$ at the highest concentration studied to $124 \mathrm{~min}$ at the lowest one for the reused fibers. When the inverse of the initial rate was plotted against the inverse of the initial concentration (Figure 10B), non-linear plots were obtained, so the photodegradation of Orange $\mathrm{G}$ does not follow the Langmuir-Hinshelwood kinetic model ${ }^{[23]}$ in contrast with some other recent studies. ${ }^{[6,24]}$ It was therefore not possible to derive the apparent adsorption constant for Orange $G$ on the PS nanofiber surface. The modified fibers were removed from solution after consecutive studies and were covered in aluminum foil for several days so their reusability could be assessed and the rate of degradation was found to be enhanced (Figure 10 and Table 1). The photodegradation of Orange $\mathrm{G}$ is known to be greatly influenced by the $\mathrm{pH}$ of the aqueous media. ${ }^{[25]}$ Degradation studies were conducted at $\mathrm{pH} 3.0,4.0,6.7,10.0$ and 11.0. A plot of percentage degradation against $\mathrm{p} H$ (Figure 11) shows that the dye degrades more quickly at basic $\mathrm{pH}$ than at acidic $\mathrm{pH}$ over the same time intervals, and that the rate of degradation reaches a maximum at $\mathrm{pH} 6.7$.

\section{Conclusions}

This study has demonstrated that BODIPY embedded nanofiber mats are potentially useful for water purification. BODIPY 1 was found to have an unusually high singlet oxygen quantum yield in ethanol solution. The use of ADMA as a singlet oxygen scavenger demonstrates that the photosensitizer properties of the dye are retained when it is embedded in PS nanofibers and immersed in water. The photodegradation properties of the nanofibers for Orange $G$ were tested, since it is a relatively common wastewater pollutant. Pseudo-first order kinetics are observed, but the initial rates did not follow the Langmuir-Hinshelwood model. Somewhat enhanced photodegradation rates $\left(k_{\text {obs }}\right)$ were obtained during reusability studies. The $\mathrm{p} H$ dependence of Orange $\mathrm{G}$ was examined, and this shows that the percentage of degradation decreases at acidic and basic $\mathrm{p} H$ and reaches a maximum at neutral $\mathrm{pH}$. Since 2,6-halogented BODIPY chromophores absorb strongly in the $500-550 \mathrm{~nm}$ region where phthalocyanines absorb weakly, embedding both dyes into nanofibers can be expected to result in enhanced rates of degradation if a white light source, such as solar energy, is used.

Table 1. Photodegradation kinetics data for the BODIPY 1 embedded PS nanofibers.

\begin{tabular}{|c|c|c|c|c|}
\hline $\begin{array}{c}{[\mathrm{OG}]} \\
\left(\cdot 10^{-5} \mathrm{~mol} \cdot \mathrm{L}^{-1}\right)\end{array}$ & $\begin{array}{c}\text { Initial rate }\left(\mathrm{r}_{0}\right) \\
\left(\cdot 10^{-7} \mathrm{~mol} \cdot \mathrm{L}^{-1} \cdot \mathrm{min}^{-1}\right)\end{array}$ & $\begin{array}{l}\text { Half life }\left(\tau_{1 / 2}\right) \\
\text { (min) }\end{array}$ & $\begin{array}{l}\text { Degradation } \%(\eta) \\
(\% \text { at } 30 \mathrm{~min})\end{array}$ & $\begin{array}{c}k_{\text {obs }} \\
\left(\cdot 10^{-3} \min ^{-1}\right)\end{array}$ \\
\hline \multicolumn{5}{|c|}{ first use of nanofibers } \\
\hline 4.1 & 1.84 & 154.0 & 13.7 & 4.5 \\
\hline 6.4 & 3.91 & 113.6 & 26.5 & 6.1 \\
\hline 9.3 & 8.79 & 73.0 & 28.9 & 9.5 \\
\hline 11.8 & 13.1 & 62.4 & 31.9 & 11.1 \\
\hline \multicolumn{5}{|c|}{ reuse of nanofibers } \\
\hline 3.3 & 1.86 & 123.8 & 14.9 & 5.6 \\
\hline 6.2 & 7.30 & 59.2 & 32.7 & 11.7 \\
\hline 9.0 & 14.3 & 43.6 & 38.6 & 15.9 \\
\hline 11.8 & 29.8 & 27.5 & 54.8 & 25.2 \\
\hline
\end{tabular}



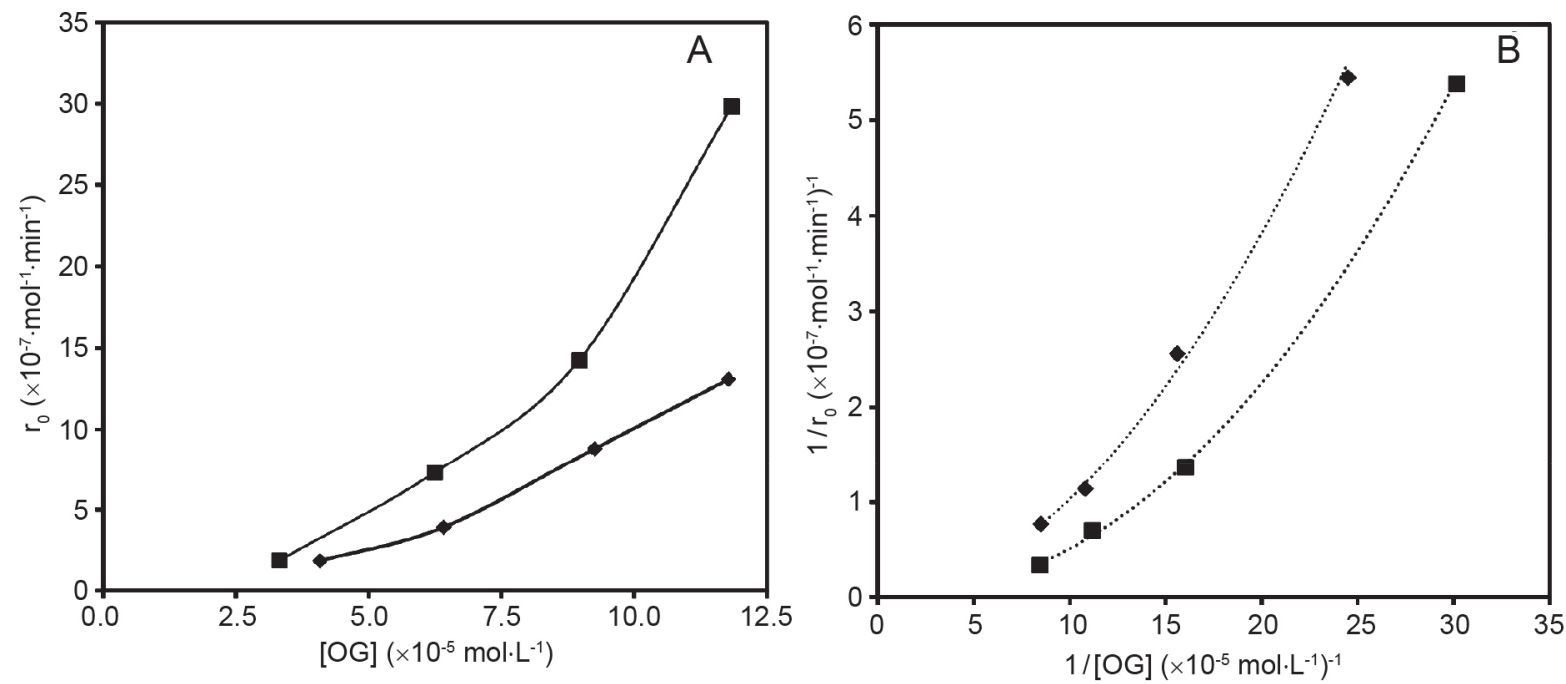

Figure 10. (A) The initial rate of photodegradation of Orange G versus initial concentration during the initial consecutive use of BODIPY 1 embedded PS nanofibers as catalysts in water (diamonds) and their subsequent reuse (squares). (B) The inverse of the initial rate of photodegradation of Orange $\mathrm{G}$ versus the inverse of the initial concentration.

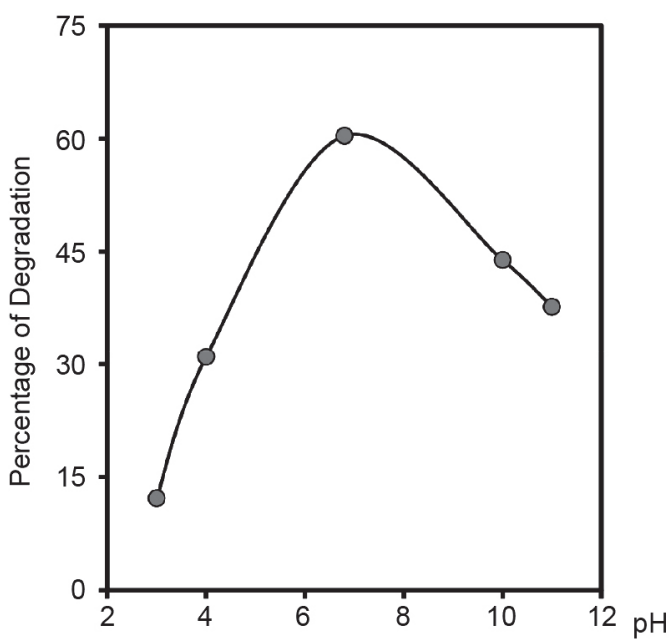

Figure 11. Effect of $\mathrm{pH}$ on the percentage of degradation of Orange $\mathrm{G}$ with a $530 \mathrm{~nm}$ LED (Orange G $\left.1.5 \cdot 10^{-4} \mathrm{~mol}^{-1} \cdot \mathrm{L}\right)$, catalyst nanofibers $25 \mathrm{mg}$, time of irradiation $3 \mathrm{~h}$ ).

Acknowledgements. This work was supported by the Department of Science and Technology (DST) and National Research Foundation (NRF) of South Africa through DST/ NRF South African Research Chairs Initiative for Professor of Medicinal Chemistry and Nanotechnology (uid: 62620), a CSUR grant from the NRF of South Africa to JM (uid: 93627). Photophysical measurements were made possible by the Laser Rental Pool Programme of the Council for Scientific and Industrial Research (CSIR) of South Africa.

\section{References}

1. Stylidi M.M., Kondarides D.I., Verykios X.E. Appl. Catal. 2004, 47, 189-201.
2. Robinson T., McMullan G., Marchant R., Nigam P. Bioresour. Technol. 2001, 77, 247-255.

3. Dominguez C., Garcia J., Pedraz M., Torres A., Galan M. Catal. Today 1998, 40, 85-101.

4. Liu B., Fang Y., Li Z., Xu S. J. Nanosci. Nanotechnol. 2015, 15, 889-920.

5. Modisha P., Nyokong T. J. Mol. Catal. A 2014, 381, 132-137.

6. Mapukata S., Chindeka F., Sekhosana K.E., Nyokong T. Mol. Catal. 2017, 439, 211-223.

7. Zugle R., Nyokong T. J. Appl. Polym. Sci. 2013, 128, 11311142.

8. Li Z., Zhang J., Yu L., Zhang J. J. Mater. Sci. 2017, 52, 61736195.

9. Loudet A., Burgess K. Chem. Rev. 2007, 107, 4891-4932.

10. Ulrich G., Ziessel R., Harriman A. Angew. Chem. Int. Ed. 2008, 47, 1184-1201.

11. Lu H., Mack J., Yang Y., Shen Z. Chem. Soc. Rev. 2014, 43, 4778-4823.

12. Kamkaew A., Lim S.H., Lee H.B., Kiew L.V., Chung L.Y., Burgess K. Chem. Soc. Rev. 2013, 42, 77-88.

13. Adarsh N., Avirah R.R., Ramaiah D. Org. Lett. 2010, 12, 5720-5723.

14. Mu Y., Guo D., Hou Y., Wang S. Text. Res. J. 2017, 87, 17951805.

15. Li W., Xie Z., Jing X. Catal. Commun. 2011, 16, 94-97.

16. Kubheka G., Mack J., Kobayashi N., Kimura M., Nyokong T. J. Porphyrins Phthalocyanines 2017, 21, 523-531.

17. Frey-Forgues S., Lavabre D. J. Chem. Educ. 1999, 76, 12601260.

18. Kubin R.F., Fletcher A.N. J. Lumin. 1982, 27, 455-462.

19. Gandin E., Lion Y., van de Vorst A. Photochem. Photobiol. 1983, 37, 271-278.

20. Spiller W., Kliesch H., Wohrle D., Hackbarth S., Roder B., Schnurpfeil G. J. Porphyrins Phthalocyanines 1998, 2, 145-158.

21. Ngoy B.P., Molupe N., Harris J., Fomo G., Mack J., Nyokong T. J. Porphyrins Phthalocyanines 2017, 21, 431-438.

22. Meetani M., Rauf M., Hisaindee S., Khaleel A., AlZamly A., Ahmad A. RSC Adv. 2011, 1, 490-497.

23. Kumar K.V., Porkodi K., Rocha F. Catal. Commun. 2008, 9, 82-84.

24. Khoza P., Nyokong T. J. Mol. Catal. A 2015, 399, 25-32.

25. Akpan U., Hameed B. J. Hazard. Mater. 2009, 170, 520-529. 